\title{
Eksploratory Faktor Analisis Pengembangan Layanan Pariwisata Digital Penelitian Kualitatif dengan Metode Theme Analytic
}

\author{
Daduk Merdika Mansur ${ }^{1}$, Ernie Tisnawati Sule ${ }^{2}$, Dwi Kartini ${ }^{3}$, \\ Yevis Marty Oesman ${ }^{4}$, Nurul Chamidah ${ }^{5}$ \\ ${ }^{1,2,3,4}$ Universitas Padjadjaran \\ ${ }^{5}$ Universitas Gajah Mada \\ daduk16001@mail.unpad.ac.id
}

\begin{abstract}
ABSTRAK
Pariwisata salah satu faktor penting penopang ekonomi Indonesia. Pengembangan layanan pariwisata digital merupakan terobosan penting untuk meningkatkan perkembangan pariwisata. Hal ini dapat menciptakan brand awareness, engagement, sales bahkan loyalty.Tujuan penelitian ini untuk mengetahui faktor yang dominan berpengaruh kepada penerimaan dan penggunaan layanan digital. Pengambilan sampel dengan teknik Purpose Sampling, menggunakan teknik observasi, wawancara, kuisioner, dan dokumentasi. Data yang diperoleh dianalisis dengan metode Theme Analytic.Hasil penelitian menunjukan faktor Performance Expectancy yang dominan Membantu Proses Pembelian (51,72\%), Effort Expectancy yang dominan Merasa Ahli menggunakan (45,06\%), Social Influence yang dominan Faktor Sosial penggunaan layanan digital $(77,14 \%)$, Facilitating Condition yang dominan Ketersediaan Resource $(68,06 \%)$, Habit yang dominan Pelaksanaan perilaku sebesar (68,68\%), Perceive Risk dimensi yang dominan Resiko Kerugian performansi (52,8\%), Perceive Convenience yang dominan Kenyamanan Menggunakan (31,05\%) dan Trush yang dominan Kemampuan Provider (48,37\%).Kunci keberhasilan pengambangan layanan digital adalah benar-benar memenuhi requirement digital consumer buying behavior yang merupakan faktor penting dalam konsep Market Driven pada era industry 4.0. Perlu dilakukan uji coba validasi terhadap layanan pariwisata digital untuk mengukur tingkat penerimaannya serta dilakukan program improvement.

Kata kunci: Layanan pariwisata digital, Perilaku pengguna digital, Digital Pariwisata, Behavior Intention Digital Tourism, Use Behavior Digital Tourism
\end{abstract}

\begin{abstract}
Tourism is one of the important factors supporting Indonesia's economy. The development of digital tourism services is an important breakthrough to enhance the development of tourism. This can create brand awareness, engagement, sales and even loyalty.The purpose of this study was to determine the dominant factors affecting the reception and use of digital services. Sampling with Purpose Sampling technique, using observation, interviews, questionnaires, and documentation. The data obtained were analyzed using the Theme Analytic method.The results showed Performance Expectancy the dominant factor is Helping the Purchasing Process (51.72\%), Effort Expectancy the dominant factor is Feeling Expert (45.06\%), Social Influence the dominant factor is Social Factors using digital services (77.14\%), Facilitating Conditions the dominant factor is Resource Availability (68.06\%), Habit the dominant factor is Implementation behavior (68.68\%), Perceive Risk the dominant factor is Performance Loss Risk (52.8\%), Perceive Convenience the dominant factor is Comfort Using (31.05\% ) and the Trush the dominant factor is Ability Provider (48.37\%).The key to the success of floating digital services is to truly meet the requirements of digital consumer buying behavior which is an important factor in the concept of Market Driven in the industrial era 4.0. It is necessary to test the validation of digital tourism services to measure the level of acceptance and improvement programs. Keywords: Digital tourism services, Digital user behavior, Digital Tourism, Behavior Intention Digital Tourism, Use Behavior Digital Tourism
\end{abstract}

Diterima: 20 Agustus 2019, Direvisi: 15 November 2019, Diterbitkan: 15 Februari 2020. 


\section{PENDAHULUAN}

Indonesia adalah negara maritim yang memiliki kekayaan destinasi wisata keindahan pantai yang mempesona. Potensi ini menjadi daya tarik bagi wisatawan dan menjadi superior customer value untuk mendatangkan wisatawan manca negara. Hal ini mendorong sektor pariwisata menjadi sangat strategis menopang ketahanan ekonomi nasional. Berdasarkan Rencana Pembangunan Jangka Menengah Nasional (RPJMN) 2015 $2019^{[1]}$ yang menetapkan 5 (lima) Fokus Program Pembangunan Lima Tahun ke depan yaitu
Infrastruktur, Maritim, Energi, Pangan dan Pariwisata (IMEPP). Presiden RI melalui Rapat Terbatas di Jakarta pada awal tahun 2015 telah menetapkan Pariwisata sebagai Leading Sector pembangunan Indonesia dan seluruh kementerian lainnya wajib mendukung.

Landasan konseptual mekanisme proses kegiatan lingkup pariwisata dalam konsteks sistemnya, demi kepuasan untuk berbagai pihak diilustrasikan melalui Gambar 1. Sistem Pariwisata, sebagai berikut:

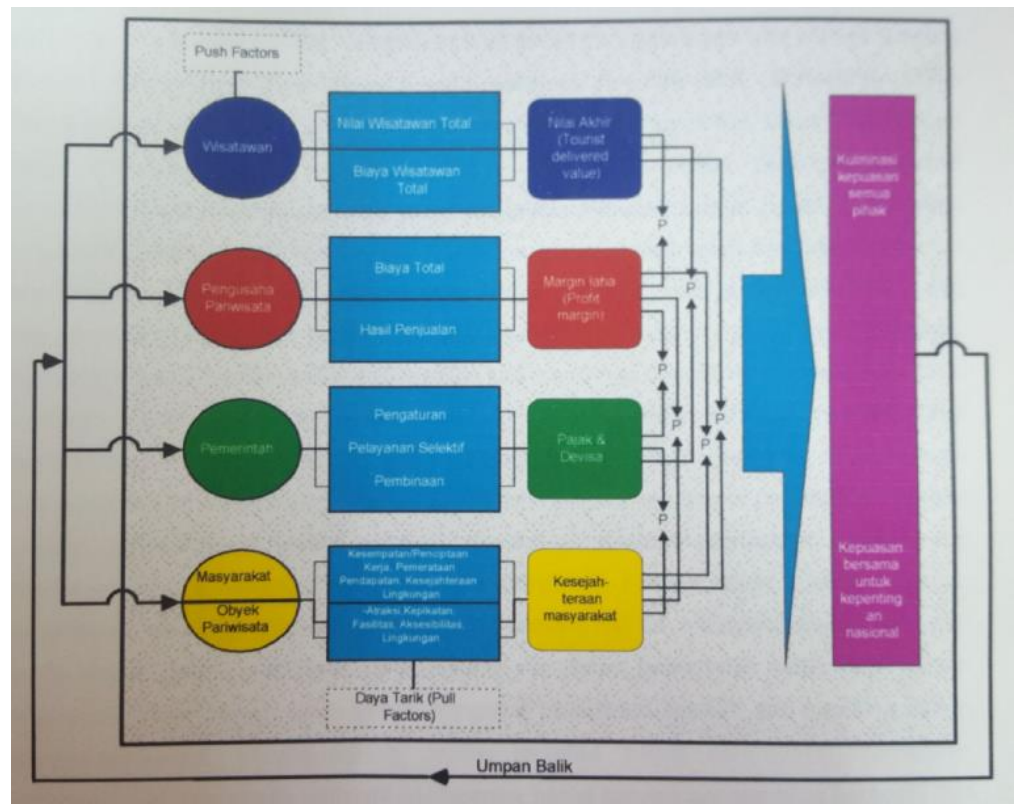

Gambar 1. Sistem Pariwisata

Gambar 1 mengilustrasikan mekanisme proses kegiatan lingkup Pariwisata dalam konteks sistemnya untuk kepuasan pada key stakeholders. Sistem Pariwisata ibarat suatu organisasi, baik internal maupun eksternal. Para pelaku tersebut dilihat dari dua sisi: selaku pengguna jasa wisata dari sisi permintaan yaitu kelompok wisatawan yang biasa juga disebut sebagai konsumen eksternal; sedangkan selaku penyedia jasa dari sisi penawaran, terdiri dari pengusaha pariwisata, pemerintah, dan masyarakat setempat termasuk wisatawan total (total tourist cost). Nilai wisatawan total terdiri dari gabungan nilai produk (barang dan jasa), nilai sumber daya manusia yang melayani, dan nilai citra. Sedangkan biaya wisatawan total merupakan gabungan dari nilai uang (monetary price), biaya waktu, biaya energy, dan biaya psikis (psychic cost). Nilai akhir wisatawan tersebut sangat relatif, sedangkan pengusaha mengharapkan lokasi/objek pariwisata. Secara organisasi, antar keseluruhan pelaku merupakan konsumen internal. Pengusaha pariwisata dalam sistem ini ditinjau dari seluruh industri, artinya termasuk pula para pesaing. Setiap pelaku memiliki misi, tujuan, dan harapannya masing-masing. Wisatawan mengharapkan suatu nilai akhir (tourist delivered value). Nilai akhir tersebut merupakan kelebihan relative nilai wisatawan total (total tourist value) dari biaya

margin laba. Masyarakat setempat harus ditingkatkan kesadarannya dan diikutsertakan untuk turut memberikan pelayanan kepada wisatawan. Lokasi dan objek wisata termasuk masyarakat setempat merupakan produk yang ditawarkan, juga diharapkan dapat memiliki daya tarik melalui faktor atraksi, fasilitas, aksesibilitas, dan lingkungannya. Selain itu dalam lingkup masyarakat terdapat komunitas atau mass media 
yang membantu mempromosikan lokasi \& objek wisata. Pemerintah dalam hal ini mengharapkan pajak dan devisa untuk sepenuhnya mengemban misi trifungsi, yaitu selaku pengatur, pelayanan selektif, dan Pembina dalam konteks pariwisata. Dari kelima pelaku wisata pentahelix dalam penelitian ini yang akan disoroti dalam penelitian difokuskan pada wisatawan sebagai pengguna jasa wisata atau consumer. Era digital menggeser perilaku manusia dari kesulitan menjadi kemudahan dan dari daya jangkau sangat luas dari berbagai potensi penting bagi tumbuhnya bisnis digital. Demikian juga Sektor pariwisata harus menyediakan layanan secara digital. Sebuah layanan digital yang cocok dengan perilaku pengguna perlu dikembangkan. Karakter bisnis digital yaitu the winner takes all menjadi hal krusial dalam pengembangan bisnis digital. Hasil penelitian penerimaan dan penggunaan layanan digital menunjukan bahwa bisnis digital rentan dengan isu negative karena cepat viral, sehingga pengembangan layanan digital untuk bisnis pariwisata harus benar-benar didesign dengan cermat dan tepat ${ }^{[3]}$. Disinyalir banyak dari

\section{KAJIAN PUSTAKA}

Layanan pariwisata digital berkaitan dengan konsep market driven yang merujuk kepada Strategic Marketing Management ${ }^{[2]}$. Market Driven Strategy yaitu proses Marketing Management yang mengatur proses penciptaan, mengkomunikasikan, dan menyampaikan value kepada customer dalam rangka menghasilkan keuntungan bagi organisasi dan stake holder. Perusahaan harus mampu mendeliver Superior Value kepada customer sehingga dapat memahami keinginan dan kebutuhan customer. para pengembang bisnis digital terjebak dalam kecanggihan dan tidak sesuai dengan perilaku dan keinginan pengguna sehingga tidak diterima oleh pasar. Berdasarkan kondisi ini perlu dibuat sebuah acuan konsep dalam pengembangan layanan digital pariwisata.

\section{Rumusan dan Tujuan Masalah}

Fakta-fakta yang di ungkapkan tersebut memberikan gambaran tentang pentingnya mengembangkan layanan pariwisata digital seperti apa yang akan diterima oleh market digital. Penelitian kualitatif sebagai dasar pengembangan aplikasi layanan pariwisata digital ini adalah untuk mengetahui faktor apa saja yang dominan dikaitkan dengan perilaku pengguna layanan pariwisata digital.

\section{Kegunaan Penelitian}

Hasil penelitian ini akan memperkaya kazanah keilmuan dalam bidang perilaku pengguna digital. Hasil penelitian juga sangat berguna bagi Provider Layanan Pariwisata Digital dalam mengembangkan Platform Layanannya.

Perusahaan harus mampu mengimprove layanan yang memenuhi kebutuhan customer.

Studi tentang perilaku pelanggan adalah studi mengenai bagaimana seseorang mengalokasikan sumberdayanya untuk dipergunakan dalam proses pembelian. Keberagaman latar belakang dan karakter konsumen menjadi hal penting dalam menentukan perilaku pembelian ${ }^{[4]}$. Pada penelitian ini perilaku tersebut akan dipelajari dan diuji coba serta dilakukan pengukuran dari hasil survey. CONSUMER BUYING BEHAVIOR

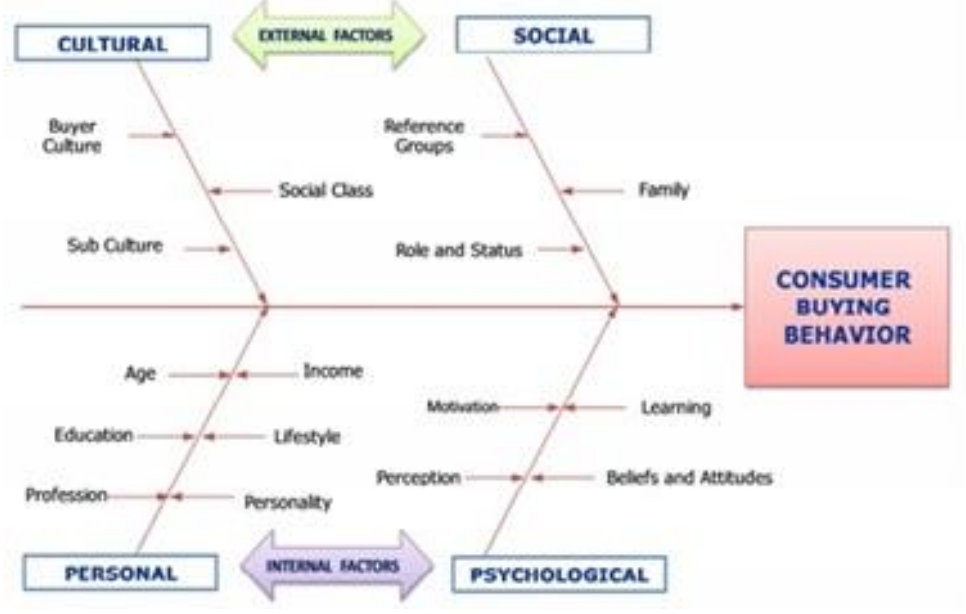


Gambar 2. Faktor-faktor yang mempengaruhi perilaku pembelian ${ }^{[4]}$

Diagram ini memberikan informasi bahwa ada empat hal yang mempemengaruhi perilaku pembelian yaitu (1) budaya, (2) sosial, (3) pribadi dan (4) psikologis. Diperlukan sebuah proses untuk memahami konsumen membuat keputusan pembelian oleh pemasar.

Aspek layanan digital penelitian ini merujuk pada teori digital marketing yang memiliki keterkaitan kuat dengan perilaku konsumen pengguna layanan online. Menurut teori yang menjadi bahasan dalam penelitian atau teori digital marketing adalah mencakup tigal hal penting yaitu berkaitan dengan aspek Environment, Company dan Outcome ${ }^{[5]}$. Lebih jelasnya penjelasan digital marketing adalah sebagaimana gambar

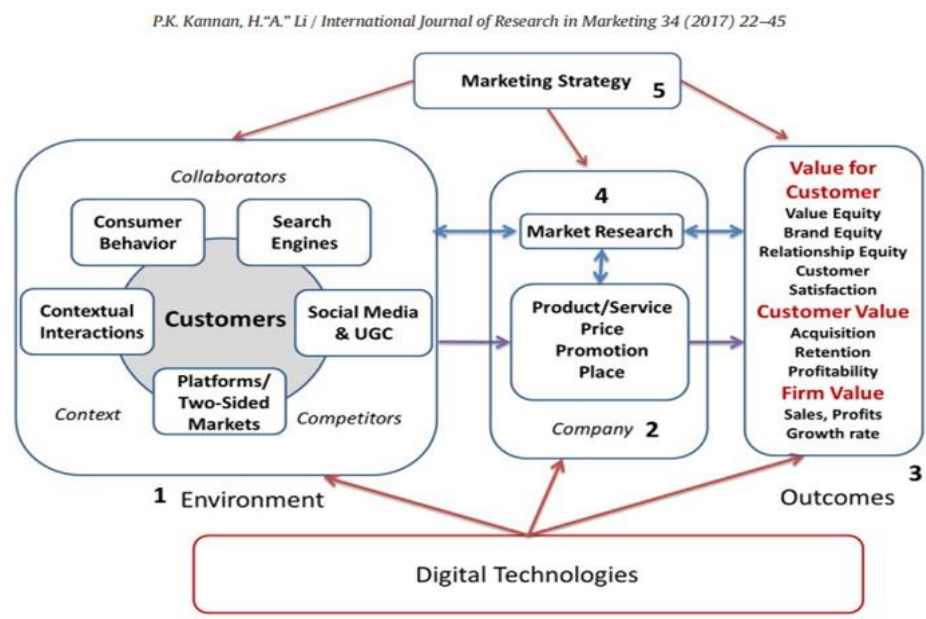

Gambar 3. Konsep teori marketing digital ${ }^{[5]}$

Teori digital marketing ini memberikan penjelasan bahwa perilaku pelanggan pada layanan yang bersifat digital online akan terjadi perubahan atau perbedaan yang signifikan. Semua kebijakan dan fokus perusahaan yang memiliki pelanggan layanan digital harus menyesuaikan dan bisa memberikan kepuasan secara maksimal. Layanan digital tentunya juga akan memberikan value yang berbeda dibanding layanan konvensional.

Penelitian penerimaan dan penggunaan layanan digital $^{[3]}$ telah membangun sebuah model penerimaan dan penggunaan layanan digital yang merupakan konsep teori yang memaparkan faktor-faktor yang berpengaruh dalam penerimaan sebuah layanan digital Performance Expectancy (PE), Effort Expectancy (EE), Social Influence (SI), Facilitating Condition (FC), Habit $(\mathrm{H})$, Perceive Risk (PR), Perceive Convenience (PC) dan Trust (T) yang berpengaruh terhadap perilaku niat penggunaan layanan digital. Dalam penelitian ini telah dikembangkan beberapa dimensi penelitian sebagai berikut:

Tabel 1 Konstruk model penerimaan layanan digital ${ }^{[3]}$

\begin{tabular}{|c|c|c|}
\hline Definisi & Dimensi & Indikator \\
\hline \multirow{2}{*}{$\begin{array}{l}\text { Performance } \\
\text { Harapectancy: } \\
\text { meningkatkan } \quad \text { sistem produktifitas dan } \\
\text { efektifitas. }\end{array}$} & Efektiv & Tingkat efektivitas membeli barang \\
\hline & & Tingkat membantu mencari barang \\
\hline \multirow{3}{*}{$\begin{array}{l}\text { Effort Expectancy: } \\
\text { Harapan kemudahan menggunakan. }\end{array}$} & Operasi & Tingkat kemudahan mengoperasikan \\
\hline & Interaksi & Tingkat kejelasan saat berinteraksi \\
\hline & Keahlian & mudahan untuk ahli menggunakan \\
\hline \multirow{2}{*}{$\begin{array}{l}\text { Sosial Influence: } \\
\text { Persepsi individual yang dipengaruhi } \\
\text { oleh persepsi orang lain dalam } \\
\text { memutuskan mempergunakan sistem. }\end{array}$} & Faktor sosial & Dukungan kolega \\
\hline & Image & Meningkatkan Image \\
\hline \multirow{2}{*}{$\begin{array}{l}\text { Facilitating Condition: } \\
\text { Keyakinan individu bahwa organisasi }\end{array}$} & Resource & Tingkat kesiapan resource \\
\hline & Knowledge & Tingkat kesiapan knowledge \\
\hline
\end{tabular}




\begin{tabular}{|c|c|c|}
\hline $\begin{array}{l}\text { dan infrstruktur telah ada dan } \\
\text { mensuport penggunaan. }\end{array}$ & Compatible & Tingkat kompatibilitas \\
\hline \multirow{2}{*}{$\begin{array}{l}\text { Habit: } \\
\text { Tindakan yang dilakukan secara } \\
\text { otomatis. }\end{array}$} & $\begin{array}{l}\begin{array}{l}\text { Pelaksanaan } \\
\text { perilaku }\end{array} \\
\end{array}$ & Tingkat keterbiasaan \\
\hline & Pengulangan & Tingkat Pengulangan \\
\hline \multirow{5}{*}{$\begin{array}{l}\text { Perceive Risk: } \\
\text { Persepsi akan hilangnya uang, barang, } \\
\text { kualitas, spek barang dan di curi data } \\
\text { personal }\end{array}$} & Resiko performansi & $\begin{array}{l}\text { Tingkat kegagalan sistem tidak bekerja } \\
\text { sesuai iklan }\end{array}$ \\
\hline & Resiko Sosial & Tingkat ketidaknyamanan berinteraksi \\
\hline & Resiko waktu & Tingkat lamanya proses transaksi \\
\hline & Resiko finansial & Kemungkinan kerugian uang \\
\hline & Resiko keamanan & Tingkat keamanan data personal \\
\hline \multirow{5}{*}{$\begin{array}{l}\text { Perceive Convenience: } \\
\text { Persepsi kenyamanan dan kemudahan } \\
\text { dalam belanja online. }\end{array}$} & Waktu & Tingkat waktu dalam transaksi \\
\hline & Tempat & Tingkat fleksibilitas tempat akses \\
\hline & Akuisisi & Tingkat kemudahan mengakuisisi \\
\hline & Penggunaan & Tingkat kemudahan penggunaan \\
\hline & Eksekusi & Tingkat kemudahan mengeksekusi \\
\hline \multirow{3}{*}{$\begin{array}{l}\text { Trust: } \\
\text { Keyakinan akan keahlian, kemampuan } \\
\text { dan integritas seseorang. }\end{array}$} & Keahlian & Hasil kerja bagus \\
\hline & Kemampuan & Hasil tuntas sesuia harapan \\
\hline & Integritas & Sesuai spesifikasi tidak ada penipuan \\
\hline
\end{tabular}

\section{METODOLOGI PENELITIAN \\ Ruang Lingkup Penelitian}

Penelitian ini melakukan pendalaman secara kualitativ atau Exploratory Factor Analysis (EFA) terhadap faktor-faktor yang mempengaruhi penerimaan layanan digital. Pendalaman secara kualitativ dilakukan terhadap faktor-faktor dalam penelitian penerimaan dan penggunaan layanan digital dengan mengacu pada hasil penelitian ${ }^{[3]}$ dengan item pertanyaan sebagaimana Tabel 2.

Tabel 2 Item pertanyaan survey ${ }^{[2]}$

\begin{tabular}{|l|l|}
\hline \multicolumn{1}{|c|}{ Variabel } & \multicolumn{1}{c|}{ Pertanyaan Terbuka } \\
\hline Performance Expectancy $(P E)$ & $\begin{array}{l}\text { Manfaat performansi apa yang diharapkan dari penggunaan } \\
\text { layanan pariwisata digital? }\end{array}$ \\
\hline Effort Expectancy $(E E)$ & $\begin{array}{l}\text { Kemudahan apa yang diharapkan dari penggunaan layanan } \\
\text { pariwisata digital? }\end{array}$ \\
\hline Social Influence $(S I)$ & $\begin{array}{l}\text { Pengaruh sosial apa yang mempengaruhi penggunaan } \\
\text { layanan pariwisata digital? }\end{array}$ \\
\hline Facilitating Condition $(F C)$ & $\begin{array}{l}\text { Fasilitas apa yang diharapkan tersedia untuk mensuport } \\
\text { penggunaan layanan pariwisata digital? }\end{array}$ \\
\hline Habit $(H)$ & $\begin{array}{l}\text { Kebiasaan apa yang mempengaruhi penggunaan layanan } \\
\text { pariwisata digital? }\end{array}$ \\
\hline Perceive Risk $(P R)$ & $\begin{array}{l}\text { Resiko apa yang mempengaruhi penggunaan layanan } \\
\text { pariwisata digital? }\end{array}$ \\
\hline Perceive Convenience $(P C)$ & $\begin{array}{l}\text { Kenyamanan apa yang diharapkan dari penggunaan } \\
\text { layanan pariwisata digital? }\end{array}$ \\
\hline Trust $(T)$ & $\begin{array}{l}\text { Kepercayaan terkait apa yang mempengaruhi penggunaan } \\
\text { layanan pariwisata digital? }\end{array}$ \\
\hline
\end{tabular}

\section{Teknik Analisa Data}

Pendalaman secara exploratory dilakukan dengan cara menganalisa jawaban terbuka responden (selayaknya disebut pengguna). Semua jawaban tersebut dianalisis dengan menggunakan metode Semua jawaban dari pengguna dilakukan Analisa untuk memahami need and want dari pengguna.

\section{HASIL DAN PEMBAHASAN}

Trend pengembangan layanan digital yang merambah semua sector menjadi faktor penting dalam paradigma baru bisnis pariwisata. Sebagai sektor yang mendapat prioritas penting dalam kebijakan pemerintah, maka layanan digital
Theme Analytic ${ }^{[6]}$ dengan merujuk pada teori hasil penelitian ${ }^{[3]}$. Pengelompokkan jawaban pengguna ini untuk menentukan faktor dimensi yang dominan dan gambaran persepsi pengguna layanan digital.

pariwisata merupakan pilar yang sangat strategis. Wisatawan yang merupakan pengguna layanan ini memiliki behavior pengguna digital dan memiliki selera menikmati kenyamanan dalam berwisata. Hal-hal unik dan bercirikhas leisure ini menjadi kunci penting dalam pengembangan layanan pariwisata digital. Pengambilan data dilakukan pada pengguna layanan digital aktiv yang memang sudah terbiasa dalam penggunaan 
layanan digital terutama yang mengalami proses data sebagai berikut: transaksi secara online. Adapun hasil rekapan

Tabel 3. Rekapitulasi Data Survey

\begin{tabular}{|c|c|c|c|}
\hline & Data Masuk & Tidak Lengkap & Data Valid (\%) \\
\hline Responden & $822(100 \%)$ & $222(27 \%)$ & $600(73 \%)$ \\
\hline Variabel & Mengisi jawaban & Tidak mengisi & Data (\%) \\
\hline $\mathrm{PE}$ & 582 & 18 & $97 \%$ \\
\hline $\mathrm{EE}$ & 502 & 98 & $83,7 \%$ \\
\hline SI & 432 & 168 & $72 \%$ \\
\hline $\mathrm{FC}$ & 407 & 193 & $67,8 \%$ \\
\hline $\mathrm{H}$ & 512 & 88 & $85 \%$ \\
\hline PR & 571 & 29 & $95 \%$ \\
\hline $\mathrm{PC}$ & 548 & 52 & $91 \%$ \\
\hline $\mathrm{T}$ & 519 & 81 & $86,5 \%$ \\
\hline GENDER & \multicolumn{2}{|c|}{ JUMLAH } & PROSENTASE \\
\hline Male & \multicolumn{2}{|c|}{413} & $69 \%$ \\
\hline Female & \multicolumn{2}{|c|}{187} & $31 \%$ \\
\hline \multicolumn{4}{|l|}{ AGE } \\
\hline$<20$ Tahun & \multicolumn{2}{|c|}{29} & $4.83 \%$ \\
\hline 20 sd 30 Tahun & \multicolumn{2}{|c|}{218} & $36.33 \%$ \\
\hline 30 sd 40 Tahun & \multicolumn{2}{|c|}{236} & $39.33 \%$ \\
\hline 40 sd 45 Tahun & \multicolumn{2}{|c|}{117} & $19.50 \%$ \\
\hline \multicolumn{4}{|l|}{ TRANSACTION } \\
\hline$>1 \mathrm{Jt}$ & \multicolumn{2}{|c|}{89} & $14.8 \%$ \\
\hline $500 \mathrm{rb} \mathrm{sd} 1 \mathrm{Jt}$ & \multicolumn{2}{|c|}{111} & $18.5 \%$ \\
\hline $250 \mathrm{rb} \mathrm{sd} 500 \mathrm{rb}$ & \multicolumn{2}{|c|}{196} & $32.7 \%$ \\
\hline$<250 \mathrm{rb}$ & \multicolumn{2}{|c|}{204} & $34 \%$ \\
\hline \multicolumn{4}{|l|}{ EDUCATION } \\
\hline SMU & \multicolumn{2}{|c|}{35} & $5.8 \%$ \\
\hline D3 & \multicolumn{2}{|c|}{215} & $35.8 \%$ \\
\hline S1 & \multicolumn{2}{|c|}{300} & $50 \%$ \\
\hline $\mathrm{S} 2 / \mathrm{S} 3$ & \multicolumn{2}{|c|}{50} & $8.3 \%$ \\
\hline
\end{tabular}

Pendalaman secara kualitatif menggunakan metode Theme Analytic (TA) dengan pendekatan teori dari model dalam penelitian [6]. Proses yang dilakukan yaitu mengelompokan jawaban terbuka responden dalam tema atau dimensi. Hasil interpretasi ini yang kemudian menjadi dasar pengelompokan setiap jawaban pengguna kedalam masing-masing dimensi.
Analisa Theme Analytic jawaban terbuka berkaitan variabel $P E$

Layanan digital harus mampu menghadirkan kebermanfaatan bagi penggunanya harus bisa dipenuhi oleh layanan yang dislenggarakan oleh provider. Hasil pengelompokan jawaban terbuka berkaitan dengan tingkat kemudahan sebuah layanan aplikasi digital adalah sebagaimana Tabel 4. 
Tabel 4. Hasil kualitatif Theme Analytic Variabel Performace Expectancy

\begin{tabular}{|c|c|c|c|c|c|}
\hline DIMENSI & GENDER & & AGE & TRANS & AKSI \\
\hline $\begin{array}{l}\text { Efektive (146 org, } \\
25.09 \% \text { ) }\end{array}$ & $\begin{array}{l}\mathrm{P}=103 \\
\mathrm{~W}=42\end{array}$ & $\begin{array}{l}>20 \text { th } \\
20 \mathrm{sd} 30 \text { th } \\
30 \mathrm{sd} 40 \text { th } \\
40 \mathrm{sd} 45 \text { th }\end{array}$ & $\begin{array}{l}4 \text { org, } \\
43 \text { org, } \\
66 \text { org, } \\
23 \text { org }\end{array}$ & $\begin{array}{l}>1 \mathrm{jt} \\
500 \mathrm{rb} \text { sd } 1 \mathrm{jt} \\
250 \mathrm{rb} \text { sd 500rb } \\
<250 \mathrm{rb}\end{array}$ & $\begin{array}{l}23 \text { org, } \\
35 \text { org, } \\
51 \text { org, } \\
37 \text { org }\end{array}$ \\
\hline
\end{tabular}

banyak pilihan, best interface, efektiv, efisien, friendly app, info produk, perbandingan barang, perbandingan harga, performa aplikasi, searching, stabilitas layanan, tampilan simple, tracking, validitas info

\begin{tabular}{|c|c|c|c|c|c|}
\hline $\begin{array}{lr}\begin{array}{l}\text { Membantu } \\
\text { pembelian }\end{array} & \text { proses } \\
\text { org, } 51,72 \%) & \end{array}$ & $\begin{array}{l}\text { P 221, } \\
\text { W } 79\end{array}$ & $\begin{array}{l}<20 \text { th } \\
20 \mathrm{sd} 30 \text { th } \\
30 \mathrm{sd} 40 \text { th } \\
40 \mathrm{sd} 45 \text { th }\end{array}$ & $\begin{array}{c}16 \text { org, } \\
103 \text { org, } \\
115 \text { org, } \\
53 \text { org }\end{array}$ & $\begin{array}{l}>1 \mathrm{jt} \\
500 \mathrm{rb} \text { sd } 1 \mathrm{jt} \\
250 \mathrm{rb} \text { sd 500rb } \\
<250 \mathrm{rb}\end{array}$ & $\begin{array}{l}47 \text { org, } \\
63 \text { org, } \\
99 \text { org, } \\
90 \text { org }\end{array}$ \\
\hline
\end{tabular}

bebas ongkos kirim, cashback, cicilan, Cash on Delivery, Trust, diskon, fasilitas jd pelapak, garansi, harga murah, pelapak berkualitas, keamanan, kualitas, aman transaksi, kapasitas layanan, kesesuaian produk, ketersediaan, pengurangan biaya ongkos kirim, kredit, kualitas barang, kualitas delivery, kualitas layanan, kualitas pelapak, return, reward, sale, Trust

\begin{tabular}{|c|c|c|c|c|}
\hline $\begin{array}{l}\text { Kemudahan proses } \\
\text { berbelanja (71 org, } \\
12.2 \% \text { ) }\end{array}$ & $\begin{array}{l}\text { P 50, } \\
\text { W } 21\end{array}$ & $\begin{array}{l}<20 \text { th } \\
20 \mathrm{sd} 30 \text { th } \\
30 \mathrm{sd} 40 \text { th } \\
40 \mathrm{sd} 45 \mathrm{th}\end{array}$ & $\begin{array}{l}2 \text { org, } \\
26 \text { org, } \\
23 \text { org, } \\
38 \text { org }\end{array}$ & $\begin{array}{lr}>1 \mathrm{jt} & 5 \text { org, } \\
500 \mathrm{rb} \text { sd } 1 \mathrm{jt} & 18 \text { org, } \\
250 \mathrm{rb} \text { sd } 500 \mathrm{rb} & 32 \mathrm{org}, \\
<250 \mathrm{rb} & 15 \mathrm{org}\end{array}$ \\
\hline
\end{tabular}

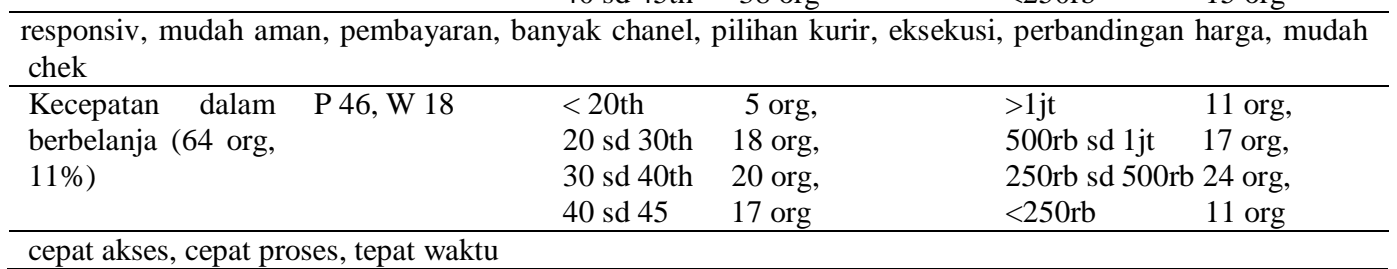

Hasil pengolahan menunjukkan bahwa jawaban terbanyak mengarah kepada dimensi Membantu Proses Pembelian sebesar $51,72 \%$ dengan dominasi terbesar pada pengguna berusia 20 th sd. 40 th. Pengguna pada usia ini adalah usia produktif dan memiliki potensi pelanggan yang loyal untuk masa yang akan datang. Pengguna layanan digital merasakan betul manfaat dalam proses pembelian barang. Beberapa faktor yang menjadikan pengguna merasa terbantu adalah proses pembelian dengan sangat mudah, pencarian barang juga bisa dilakukan dengan cepat namun masih tetap aman dan terjamin kualitas barangnya.

\section{Analisa Theme Analytic jawaban terbuka berkaitan variabel $\boldsymbol{E} E$}

Kelebihan layanan digital adalah memberikan kemudahan dalam mengekskusinya. Variasi kemampuan pengguna dari yang ahli ataupun awam harus dapat diakomodir oleh layanan digital. Bahkan pengguna yang berusia lanjut juga harus bisa di penuhi kebutuhan kemudahan dalam penggunaan. Jika seorang pengguna yang sudah berusia lanjut dan gaptek teknologi bisa terlayani dengan baik maka ini merupakan indikator bahwa layanan digital yang dikembangkan benar-benar telah memenuhi unsur kemudahan. Sehingga layanan digital yang dikembangkan dalam proses penggunaanya tidak memerlukan effort yang besar. Karakter dan budaya masyarakat Indonesia yang cenderung tidak ingin ribet membutuhkan layanan yang memberikan tingkat effort yang sedikit. Karena itu perlu diketahui betul persepsi dari pengguna berkaitan dengan harapan tingkat kemudahan dan rendahnya effort yang harus dikeluarkan oleh pengguna. Berdasarkan jawaban terbuka responden didapatkan data seperti pada Tabel 5. 
Tabel 5. Hasil kualitatif Theme Analytic Variabel Effort Expectancy

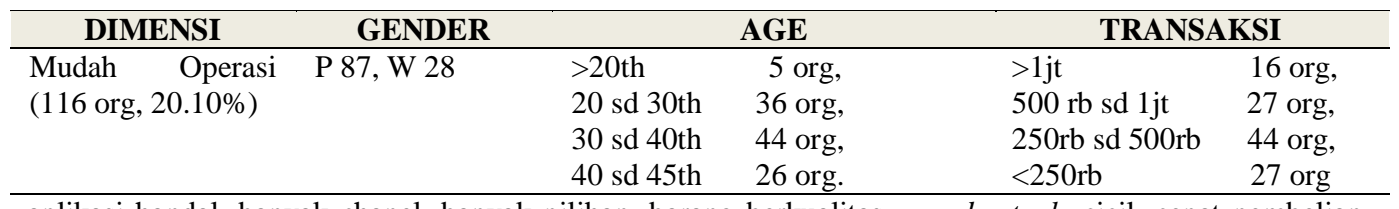

aplikasi handal, banyak chanel, banyak pilihan, barang berkualitas , ready stock, cicil, cepat pembelian, Cash On Delivery, compare, coverage pengiriman, bonus, delivery, efektiv, efisien, garansi, gratis akses, cepat proses, kemudahan, kesesuaian produk, ketersediaan, kurir banyak, lancar, layanan bagus, cicilan, barang berkualitas, pelapak berkualitas, pengiriman cepat, pilih kurir, ready stock, tempat flexibel, variasi barang

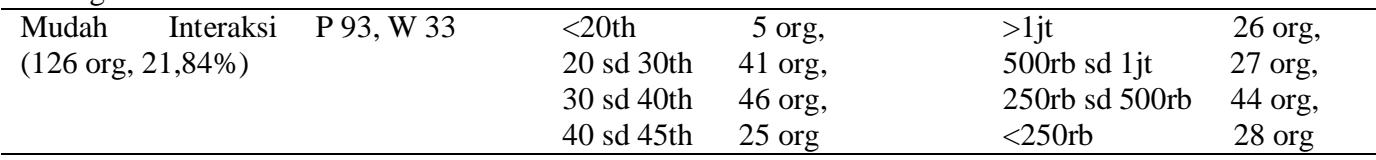

alur jelas, bonus, discon, sistem pilihan, fitur jelas, flash shale, flexibel tempat, fokus cari barang, friendly aplikasi, hadiah, info lengkap, komplain, konfirmasi pembayaran, memilih ukuran, mendapatkan kategori, menjadi reseler, mudah interaksi, mudah dapat info, mudah dapat promo, notifikasi email, pilih kurir, pilihan banyak, pilihan pembayaran, respon cepat, responsiv, return, traking, update resi, user friendly, voucher promo

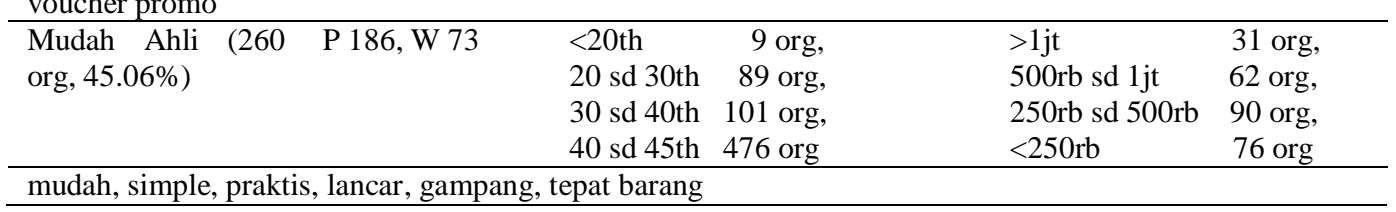

Hasil pengolahan secara kualitatif berkaitan Effort Expectancy menunjukkan bahwa jawaban terbanyak mengarah kepada dimensi Merasa Ahli saat menggunakan layanan digital sebesar $45,06 \%$ dengan dominansi pada usia 40 sd 45 th. Pengguna pada usia menengah ini sebetulnya bukan kelompok yang sangat ahli dalam ICT, namun dengan data ini menunjukan bahwa desing layanan digital dibuat hingga pengguna begitu mudah mengeksekusi dan merasa ahli dalam menggunakan. Kemudahan dan kecepatan proses pembelian membangun persepsi bahwa dengan menggunakan merasa ahli dalam proses pembelian barang.

Beberapa hal yang membuat pengguna merasa ahli tercermin dari jawaban terbuka responden bahwa penggunaan layanan pariwisata digital memberikan kemudahan dalam berbelanja, proses yang harus dilakukan juga simple, praktis, lancar, gampang, dan tepat kualitas.

\section{Analisa Theme Analytic jawaban terbuka berkaitan variabel $S I$}

Era digital online ini menimbulkan hubungan pertemanan secara sosial media sehingga hubungan pengaruh terjadi dalam interaksi sosial media. Data hasil Theme Analytic menunjukan pengguna menyatakan pengaruh terbesar adalah berkaitan dengan perihal Faktor sosial. Karakter social komunal masarakat Indonesia ini makin terkristalisasikan kuat dengan banyaknya layanan social media, tingginya frekuensi interkasi dan kemudahan dalam berkomunikasi secara digital online semakin mempercepat dan memperluas dampak pengaruh social. Sehingga hal-hal yang memiliki potensi menjadi isu akan cepat menyebar dan berpengaruh secara signifikan dalam petgaulan social masarakat. Hasil pendalaman jawaban responden sebagaimana Tabel 6.

Tabel 6. Hasil kualitatif Theme Analytic Variabel Sosial Influence

\begin{tabular}{|c|c|c|c|c|c|}
\hline \multirow{2}{*}{$\begin{array}{l}\text { DIMENSI } \\
\text { Faktor Sosial } \\
(361 \text { org, } 77.14 \%)\end{array}$} & \multirow{2}{*}{$\frac{\text { GENDER }}{\mathrm{P} 267, \mathrm{~W} 93}$} & \multicolumn{2}{|r|}{ AGE } & \multicolumn{2}{|c|}{ TRANSAKSI } \\
\hline & & $\begin{array}{l}>20 \text { th } \\
20 \mathrm{sd} 30 \text { th } \\
30 \mathrm{sd} 40 \text { th } \\
40 \mathrm{sd} 45 \mathrm{th}\end{array}$ & $\begin{array}{c}19 \text { org, } \\
118 \text { org, } \\
134 \text { org, } \\
67 \text { org }\end{array}$ & $\begin{array}{l}>1 \mathrm{jt} \\
500 \mathrm{rb} \text { sd } 1 \mathrm{jt} \\
250 \mathrm{rb} \text { sd } 500 \mathrm{rb} \\
<250 \mathrm{rb}\end{array}$ & $\begin{array}{c}62 \text { org, } \\
79 \text { org, } \\
127 \text { org, } \\
92 \text { org }\end{array}$ \\
\hline \multicolumn{6}{|c|}{$\begin{array}{l}\text { ajakan teman, isu, keluarga, komunitas, manfaat, keuntungan waktu, membantu teman, peduli sosial } \\
\text { pengaruh, perubahan teknologi, promosi }\end{array}$} \\
\hline Image & P 52, W 18 & $\begin{array}{l}<20 \text { th } \\
20 \mathrm{sd} 30 \text { th } \\
30 \mathrm{sd} 40 \text { th } \\
40 \mathrm{sd} 45 \mathrm{th}\end{array}$ & $\begin{array}{l}1 \text { org, } \\
24 \text { org, } \\
28 \text { org, } \\
12 \text { org }\end{array}$ & $\begin{array}{l}>1 \mathrm{jt} \\
500 \mathrm{rb} \text { sd } 1 \mathrm{jt} \\
250 \mathrm{rb} \text { sd } 500 \mathrm{rb} \\
<250 \mathrm{rb}\end{array}$ & $\begin{array}{l}9 \text { org, } \\
19 \text { org, } \\
26 \text { org, } \\
15 \text { org }\end{array}$ \\
\hline
\end{tabular}


Exclusif, gaya hidup, hobi, kebutuhan barang, kenyamanan, minat jualan

Hasil pengolahan secara kualitatif terhadap jawaban responden berkaitan Sosial Influence menunjukan jawaban terbanyak mengarah kepada dimensi Faktor Sosial penggunaan layanan digital sebesar $77,14 \%$ dengan dominasi usia pada rentang 20 sd 30 th. Penggunaan layanan digital pada usia ini memiliki karakter banyak dipengaruhi oleh faktor sosial secara sosial media. Perilaku masarakat sosial media ini adalah begitu intens hubungan antar satu orang dengan orang lain dan sudah menjadi bagian aktifitas setiap saat bagi para netizen yang merupakan pasar dari layanan digital.

\section{Analisa Theme Analytic jawaban terbuka berkaitan variabel $\boldsymbol{F C}$}

Layanan digital yang berbasis teknologi digital memiliki karakter yang jauh berbeda dengan sistem perdagangan konvensional. Sehingga ketersediaan sarana dan kemampuan untuk mengoperasikan layanan digital memiliki pengaruh besar dalam proses penerimaan dan penggunaanya.

Tabel 7. Hasil kualitatif Theme Analytic Variabel Facilitating Condition

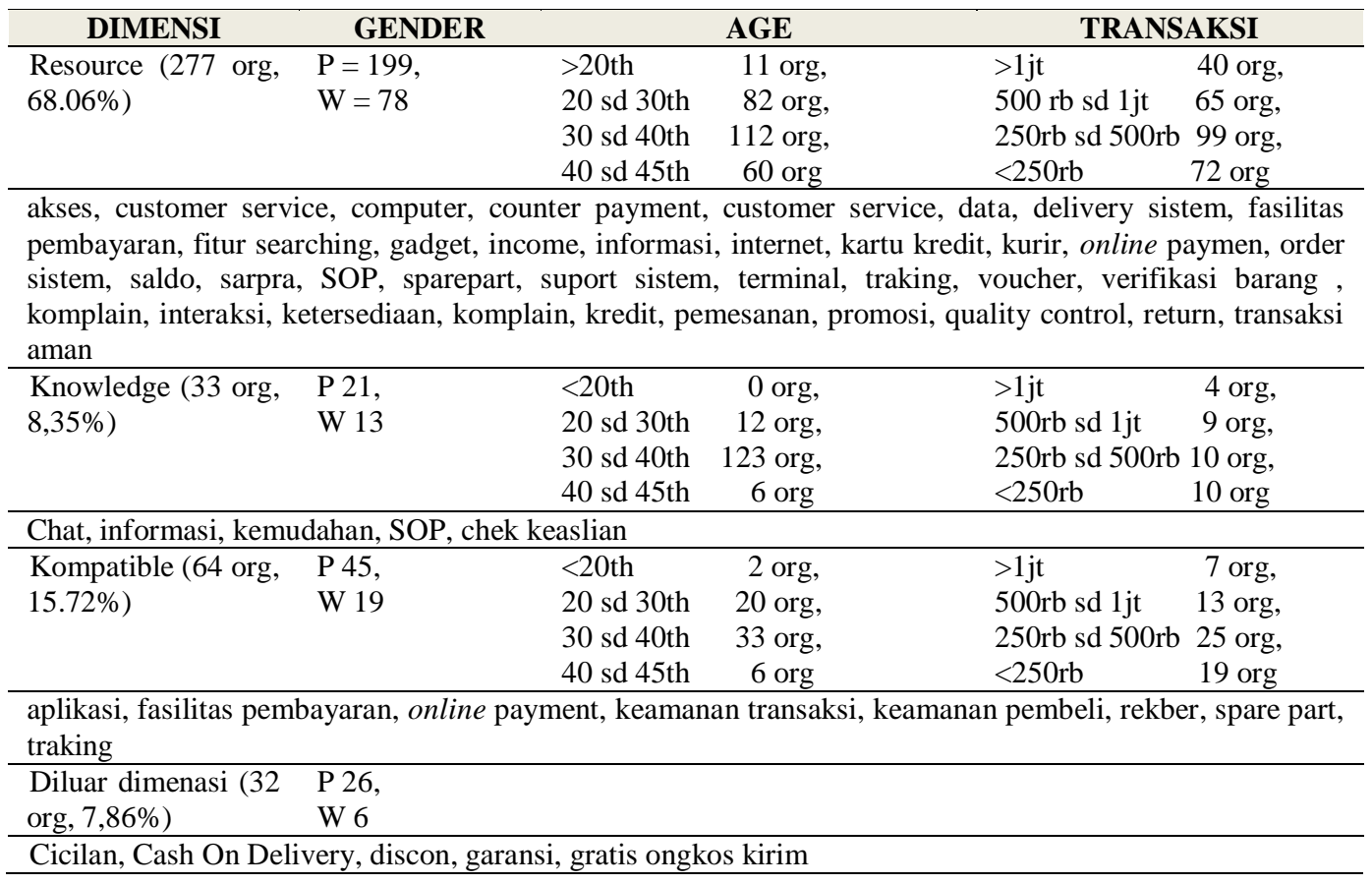

Hasil pengolahan secara kualitatif terhadap jawaban terbuka responden menunjukan bahwa jawaban terbanyak mengarah kepada dimensi Ketersediaan Resource untuk bisa menggunakan layanan digital sebesar $68,06 \%$ dengan dominasi usia diatas 30 th. Hal ini merupakan fakta bahwa pengguna dengan usia diatas 30 th yang potensial berbelanja namun merasakan banyak kekurangan ketersediaan sarana semisal alat pembayaran menggunakan kartu kredit sebagai akibat masih ragu dengan keamaanan penggunaan kartu kredit.

\section{Analisa Theme Analytic jawaban terbuka berkaitan variabel $H$}

Pengguna yang belum terbiasa online akan memiliki kendala dalam menggunakan layanan pariwisata digital. Apalagi jika layanan tersebut mengandung unsur transaksi online tentu akan sangat memunculkan rasa kawatir. Maka salah satu yang mempengaruhi keputusan penggunaan layanan digital adalah faktor kebiasaan online. Kebiasaan berkaitan dengan digital online yang sudah sering dilakukan akan mengurangi rasa kawatir berbelanja online karena mendapat layanan yang prima dan tidak mendapatkan penipuan selama bertransaksi. Hasil pengolahan jawaban terbuka jawaban responden memberikan hasil pada

Tabel. 
Tabel 8. Hasil kualitatif Theme Analytic Variabel Habit

\begin{tabular}{|c|c|c|c|c|c|}
\hline \multirow{2}{*}{\begin{tabular}{l}
\multicolumn{2}{c}{ DIMENSI } \\
Pelaksanaan \\
perilaku (353 org, \\
$68.68 \%)$
\end{tabular}} & \multirow{2}{*}{$\begin{array}{l}\text { GENDER } \\
\mathrm{P}=256 \\
\mathrm{~W}=96\end{array}$} & \multirow{2}{*}{\multicolumn{2}{|c|}{$\begin{array}{cc} & \text { AGE } \\
\text { >20th } & 13 \text { org } \\
\text { 20 sd 30th } & 105 \text { org } \\
\text { 30 sd 40th } & 144 \text { org, } \\
\text { 40 sd 45th } & 68 \text { org } \\
\end{array}$}} & \multicolumn{2}{|c|}{ TRANSAKSI } \\
\hline & & & & $\begin{array}{l}>1 \mathrm{jt} \\
500 \mathrm{rb} \mathrm{sd} 1 \mathrm{jt} \\
250 \mathrm{rb} \mathrm{sd} 500 \mathrm{rb} \\
<250 \mathrm{rb}\end{array}$ & $\begin{array}{r}55 \text { org, } \\
77 \text { org, } \\
127 \text { org, } \\
91 \text { org }\end{array}$ \\
\hline \multicolumn{6}{|c|}{$\begin{array}{l}\text { aktifitas dirumah, bayar online, belanja online, berjualan, dilivery sistem, efisiensi, hidup sehat, interaksi, } \\
\text { kredit, lihat promo, males, lihat dulu, nawar, offline, online, pemenuhan, santai, sibuk, sport }\end{array}$} \\
\hline $\begin{array}{l}\text { Pengulangan } \quad(159 \\
\text { org, } 30,93 \%)\end{array}$ & $\mathrm{P} 117, \mathrm{~W} 42$ & $\begin{array}{l}<20 \text { th } \\
20 \mathrm{sd} 30 \text { th } \\
30 \mathrm{sd} 40 \text { th } \\
40 \mathrm{sd} 45 \text { th }\end{array}$ & $\begin{array}{r}5 \text { org, } \\
64 \text { org, } \\
62 \text { org, } \\
22 \text { org }\end{array}$ & $\begin{array}{l}>1 \mathrm{jt} \\
500 \mathrm{rb} \text { sd } 1 \mathrm{jt} \\
250 \mathrm{rb} \text { sd 500rb } \\
<250 \mathrm{rb}\end{array}$ & $\begin{array}{c}26 \text { org, } \\
36 \text { org, } \\
52 \text { org, } \\
45 \text { org }\end{array}$ \\
\hline
\end{tabular}

Hasil pengolahan secara kualitatif menunjukan bahwa jawaban terbanyak mengarah kepada dimensi Pelaksanaan perilaku menggunakan layanan digital sebesar 68,68\% dengan dominasi usia pada rentang $20 \mathrm{sd} 40$ th. yang potensial untuk memiliki kebiasaan menggunakan layanan digital. Kebiasaan yang membuat pengguna internet memutuskan untuk menggunakan layanan digital adalah adanya kebiasaan aktifitas dirumah, bayar online, belanja online, berjualan, delivery sistem, efisiensi, hidup sehat, interaksi, kredit, lihat promo, males, lihat dulu, nawar, offline, online, pemenuhan, santai, sibuk, sport.

\section{Analisa Theme Analytic jawaban terbuka berkaitan variabel $P R$}

Menggunakan layanan digital tentunya tidak melihat secara al akan diterima. langsung layanan yang akan didapatkan. Hal ini tentu memunculkan resiko yang cukup besar bagi pengguna berkaitan dengan kualitas layanan yang secara reTerjadinya resiko kerugian yang mungkin dialami oleh pengguna layanan digital bisa menyebabkan timbulnya persepsi negatif dan berdampak pada tidak jadinya seseorang menggunakan layanan digital. Hasil Analisa jawaban terbuka responden seperti pada abel 9.

Tabel 9. Hasil kualitatif Theme Analytic Variabel Perceive Risk

\begin{tabular}{|c|c|c|c|c|}
\hline DIMENSI & \multicolumn{2}{|r|}{ AGE } & \multicolumn{2}{|c|}{ TRANSAKSI } \\
\hline $\begin{array}{lll}\text { Performansi } & (302 & \mathrm{P}=227 \\
\text { org, } 52.8 \%) & & \mathrm{W}=74\end{array}$ & $\begin{array}{l}>20 \text { th } \\
20 \text { sd } 30 \text { th } \\
30 \text { sd } 40 \text { th } \\
40 \text { sd } 45 \text { th }\end{array}$ & $\begin{array}{l}13 \text { org, } \\
111 \text { org, } \\
108 \text { org, } \\
56 \text { org }\end{array}$ & $\begin{array}{l}>1 \mathrm{jt} \\
500 \mathrm{rb} \text { sd } 1 \mathrm{jt} \\
250 \mathrm{rb} \text { sd } 500 \mathrm{rb} \\
<250 \mathrm{rb}\end{array}$ & $\begin{array}{l}39 \text { org, } \\
81 \text { org, } \\
99 \text { org, } \\
81 \text { org }\end{array}$ \\
\hline \multicolumn{5}{|c|}{$\begin{array}{l}\text { banyak resiko, barang rusak, barang tdk sampai, gagal pemenuhan, gagal pengiriman, gagal proses } \\
\text { kesesuaian produk, ketersediaaan, kualitas produk, pemalsuan, platform lemah, produk cacat, sistem gagal } \\
\text { salah barang, salah size }\end{array}$} \\
\hline $\begin{array}{llll}\text { Sosial } & (24 & \text { org, } & \text { P } 16, \text { W } 8 \\
4.2 \%)\end{array} \quad$ P & $\begin{array}{l}<20 \text { th org } \\
20 \text { sd } 30 \text { th } \\
30 \text { sd } 40 \text { th } \\
40 \text { sd } 45 \text { th }\end{array}$ & $\begin{array}{c}0 \text { org, } \\
12 \text { org, } \\
9 \text { org, } \\
3 \text { org }\end{array}$ & $\begin{array}{l}>1 \mathrm{jt} \\
500 \mathrm{rb} \text { sd } 1 \mathrm{jt} \\
250 \mathrm{rb} \text { sd } 500 \mathrm{rb} \\
<250 \mathrm{rb}\end{array}$ & $\begin{array}{c}6 \text { org, } \\
36 \text { org, } \\
5 \text { org, } \\
3 \text { org }\end{array}$ \\
\hline \multicolumn{5}{|c|}{$\begin{array}{l}\text { garansi, info tdk valid, kejujuran, kurang info, kurang interaksi, layanan rendah, pemalsuan, pembatala } \\
\text { sepihak, seler nakal,sulit interaksi, susah komplain, tidak profesional. Toko fiktiv }\end{array}$} \\
\hline $\begin{array}{l}\text { Waktu } \\
1.92 \%)\end{array} \quad(11 \quad$ org, $\quad$ P 8, W 3 & $\begin{array}{l}<20 \text { th } \\
20 \text { sd } 30 \text { th } \\
30 \text { sd } 40 \text { th } \\
40 \text { sd } 45 \text { th }\end{array}$ & $\begin{array}{l}1 \text { org, } \\
2 \text { org, } \\
5 \text { org, } \\
3 \text { org }\end{array}$ & $\begin{array}{l}>1 \mathrm{jt} \\
500 \mathrm{rb} \text { sd } 1 \mathrm{jt} \\
250 \mathrm{rb} \text { sd } 500 \mathrm{rb} \\
<250 \mathrm{rb}\end{array}$ & $\begin{array}{l}2 \text { org, } \\
2 \text { org, } \\
3 \text { org, } \\
4 \text { org }\end{array}$ \\
\hline \multicolumn{5}{|c|}{ komplain lama, terlambat sampai, sampai lama } \\
\hline $\begin{array}{l}\text { Financial }(34 \text { org, } \quad \text { P 29, W } 5 \\
5,94 \%)\end{array}$ & $\begin{array}{l}<20 \text { th } \\
20 \text { sd } 30 \text { th } \\
30 \text { sd } 40 \text { th } \\
40 \text { sd } 45\end{array}$ & $\begin{array}{l}\text { org, } \\
10 \text { org, } \\
16 \text { org, } \\
7 \text { org }\end{array}$ & $\begin{array}{l}>1 \mathrm{jt} \\
500 \mathrm{rb} \text { sd } 1 \mathrm{jt} \\
250 \mathrm{rb} \text { sd } 500 \mathrm{rb} \\
<250 \mathrm{rb}\end{array}$ & $\begin{array}{l}10 \text { org, } \\
2 \text { org, } \\
10 \text { org, } \\
12 \text { org }\end{array}$ \\
\hline \multicolumn{5}{|l|}{ cepat akses, cepat prose, tepat waktu } \\
\hline $\begin{array}{l}\text { Keamanan (200 org, P } 137, \text { W } 63 \\
34,97 \%)\end{array}$ & $\begin{array}{l}<20 \text { th } \\
20 \text { sd } 30 \text { th } \\
30 \text { sd } 40 \text { th } \\
40 \text { sd } 45\end{array}$ & $\begin{array}{l}9 \text { org, } \\
57 \text { org, } \\
82 \text { org, } \\
38 \text { org }\end{array}$ & $\begin{array}{l}>1 \mathrm{jt} \\
500 \mathrm{rb} \text { sd } 1 \mathrm{jt} \\
250 \mathrm{rb} \text { sd } 500 \mathrm{rb} \\
<250 \mathrm{rb}\end{array}$ & $\begin{array}{l}30 \text { org, } \\
40 \text { org, } \\
79 \text { org, } \\
51 \text { org }\end{array}$ \\
\hline
\end{tabular}


data aman, data bocor, data invalid, keamanan (barang, dana, data), pencurian data, pengiriman aman, penipuan, penyalah gunaan data

Hasil pengolahan kualitatif menggambarkan faktor resiko terbesar adalah resiko kerugian performansi $52,8 \%$ dan di ikuti oleh resiko keamanan 34,97\% pada rentang usia 20 sd 40 th. Dua hal resiko ini memang paling dominan seperti barang tidak sesuai dan dibobolnya data pribadi pembeli.

\section{Analisa Theme Analytic jawaban terbuka berkaitan variabel $P C$}

Layanan pariwisata digital yang bagian pentingnya adalah aspek leisure tentunya sangat dominan aspek kenyamanan yang diharapkan didapatkan oleh konsumen. Informasi keunggulan prima layanan pariwisata harus benar-benar tertampilkan secara maksimal pada layanan digital. Unsur seperti keramah tamahan, keindahan dan keunikan sebuah destinasi wisata harus benar-benar bisa ditampilkan dan tergambarkan secara jelas dan tidak ada dispute. Karena itu faktor kenyamanan dalam menggunakan layanan digital menjadi pertimbangan sangat utama. Simplifikasi layanan digital jangan sampai tertutup oleh ribetnya prosedur eksekusi.

Berdasarkan hasil explorasi dilapangan ditemukan fenomena masih lemahnya pemahaman oleh penyedia layanan traveling yang selama ini bergerak secara konvensional. Gap yang ada ini harus dimapingkan dan diimprove secara serius dalam layanan pariwisata digital yang dikembangkan. Berdasarkan jawaban terbuka responden didapatkan data sebagaimana pada Tabel 10.

Tabel 10. Hasil kualitatif Theme Analytic Variabel Perceive Convenience

\begin{tabular}{|c|c|c|c|c|}
\hline \multirow{2}{*}{\begin{tabular}{lll}
\multicolumn{2}{c}{ DIMENSI } & \multicolumn{1}{c}{ GENDER } \\
Waktu $(78$ org, & $\mathrm{P}=53$, \\
$14.08 \%)$ & & $\mathrm{W}=25$
\end{tabular}} & \multicolumn{2}{|c|}{ AGE } & \multicolumn{2}{|c|}{ TRANSAKSI } \\
\hline & $\begin{array}{l}>20 \text { th } \\
20 \mathrm{sd} 30 \text { th } \\
30 \mathrm{sd} 40 \text { th } \\
40 \mathrm{sd} 45 \text { th }\end{array}$ & $\begin{array}{l}2 \text { org, } \\
22 \text { org, } \\
31 \text { org, } \\
20 \text { org }\end{array}$ & $\begin{array}{l}>1 \mathrm{jt} \\
500 \mathrm{rb} \mathrm{sd} 1 \mathrm{jt} \\
250 \mathrm{rb} \text { sd } 500 \mathrm{rb} \\
<250 \mathrm{rb}\end{array}$ & $\begin{array}{l}10 \text { org, } \\
17 \text { org, } \\
32 \text { org, } \\
19 \text { org }\end{array}$ \\
\hline \multicolumn{5}{|c|}{$\begin{array}{l}\text { bisa sambil bepergian, sambil santai, efektiv belanja, gampang, info detil kebebasan memilih } \\
\text { komunikatif, mudah eksekusi, mudah milih, mudah ...., murah simpel, }\end{array}$} \\
\hline $\begin{array}{llll}\text { Tempat } & (39 \quad \text { org, } & \mathrm{P}=24 \\
7,04 \%) & & & \mathrm{W}=15\end{array}$ & $\begin{array}{l}<20 \text { th } \\
20 \mathrm{sd} 30 \text { th } \\
30 \mathrm{sd} 40 \text { th } \\
40 \mathrm{sd} 45 \text { th }\end{array}$ & $\begin{array}{l}2 \text { org, } \\
12 \text { org, } \\
13 \text { org, } \\
10 \text { org }\end{array}$ & $\begin{array}{l}>1 \mathrm{jt} \\
500 \mathrm{rb} \text { sd } 1 \mathrm{jt} \\
250 \mathrm{rb} \text { sd } 500 \mathrm{rb} \\
<250 \mathrm{rb}\end{array}$ & $\begin{array}{r}4 \text { org, } \\
8 \text { org, } \\
18 \text { org, } \\
9 \text { org }\end{array}$ \\
\hline \multicolumn{5}{|c|}{ akses dr rumah, flexibel tempat, mudah akses, tidak antri } \\
\hline $\begin{array}{lll}\text { Akuisisi }(112 \text { org, } & \mathrm{P}=83 \\
20.22 \%) & & \mathrm{W}=29\end{array}$ & $\begin{array}{l}<20 \text { th } \\
20 \mathrm{sd} 30 \text { th } \\
30 \mathrm{sd} 40 \text { th } \\
40 \mathrm{sd} 45 \text { th }\end{array}$ & $\begin{array}{l}5 \text { org, } \\
39 \text { org, } \\
43 \text { org, } \\
20 \text { org }\end{array}$ & $\begin{array}{l}>1 \mathrm{jt} \\
500 \mathrm{rb} \mathrm{sd} 1 \mathrm{jt} \\
250 \mathrm{rb} \mathrm{sd} 500 \mathrm{rb} \\
<250 \mathrm{rb}\end{array}$ & $\begin{array}{l}18 \text { org, } \\
32 \text { org, } \\
32 \text { org, } \\
29 \text { org }\end{array}$ \\
\hline \multicolumn{5}{|c|}{$\begin{array}{l}\text { delivery service, efisien, gak ribet, layanan bagus, menyenagkan, online payment, ontime delivery, } \\
\text { layamnan prima, pembayaran gampang, praktis, aman, responsiv, tidak terganggu cuaca, tdk capek, tdk } \\
\text { repot, tidak kena macet, }\end{array}$} \\
\hline $\begin{array}{lll}\text { Penggunaan } \\
\text { org, 31.05\% }\end{array} \quad\left(\begin{array}{ll}172 & \mathrm{P}=131 \mathrm{~W}=40\end{array}\right.$ & $\begin{array}{l}<20 \text { th } \\
20 \text { sd } 30 \text { th } \\
30 \text { sd } 40 \text { th } \\
40 \operatorname{sd~} 45\end{array}$ & $\begin{array}{l}8 \text { org, } \\
54 \text { org, } \\
69 \text { org, } \\
27 \text { org }\end{array}$ & $\begin{array}{l}>1 \mathrm{jt} \\
500 \mathrm{rb} \text { sd } 1 \mathrm{jt} \\
250 \mathrm{rb} \text { sd } 500 \mathrm{rb} \\
<250 \mathrm{rb}\end{array}$ & $\begin{array}{l}23 \text { org, } \\
37 \text { org, } \\
59 \text { org, } \\
50 \text { org }\end{array}$ \\
\hline \multicolumn{5}{|c|}{$\begin{array}{l}\text { aman, banyak pilihan, barang aman, bermanfaat, best price, bisa santai, cepat nyaman, cara pembayaran, } \\
\text { chat, Cash On Delivery, compare barang, data aman, fokus barang yg dibeli, gratis ongkos kirim, harga } \\
\text { jelas, jaminan kualitas, kebebasan memilih, kesesuian produk, kualitas barang, nyaman, pelapak } \\
\text { berkualiutasm layanan prima, pilih harga, privacy terjaga, produk update, promo, real belanja, refund, seler } \\
\text { kredibel }\end{array}$} \\
\hline $\begin{array}{l}\text { Eksekusi }(147 \text { org, } \quad P=111 \mathrm{~W}=35 \\
26.53 \%)\end{array}$ & $\begin{array}{l}<20 \text { th } \\
20 \mathrm{sd} 30 \text { th } \\
30 \mathrm{sd} 40 \text { th } \\
40 \mathrm{sd} 45\end{array}$ & $\begin{array}{l}5 \text { org, } \\
51 \text { org, } \\
62 \text { org, } \\
28 \text { org }\end{array}$ & $\begin{array}{l}>1 \mathrm{jt} \\
500 \mathrm{rb} \text { sd } 1 \mathrm{jt} \\
250 \mathrm{rb} \text { sd 500rb } \\
<250 \mathrm{rb}\end{array}$ & $\begin{array}{l}31 \text { org, } \\
31 \text { org, } \\
50 \text { org, } \\
35 \text { org }\end{array}$ \\
\hline
\end{tabular}

bisa sambil bepergian, sambil santai, efektiv belanja, gampang, info detil kebebasan memilih, komunikatif, mudah eksekusi, mudah milih, mudah, murah simpel,

Hasil pengolahan secara kualitatif terhadap jawaban responden berkaitan Perceive Convenience menunjukan bahwa jawaban terbanyak mengarah kepada dimensi kenyamanan saat menggunakan layanan digital sebesar $31,05 \%$ dengan profile merata disemua tingkat 
usia. Beberapa hal kenyamanan penggunaan layanan digital adalah aman, banyak pilihan, barang aman, bermanfaat, best price, bisa santai, cepat nyaman, cara pembayaran, chat, Cash On Delivery, compare barang, data aman, fokus barang yg dibeli, gratis ongkos kirim, harga jelas, jaminan kualitas, kebebasan memilih, kesesuian produk, kualitas barang, nyaman, pelapak berkualitas, layanan prima, pilih harga, privacy terjaga, produk update, promo, real belanja, refund, seler kredibel.

\section{Analisa Theme Analytic jawaban terbuka berkaitan variabel Trust $(T)$}

Semua bisnis memerlukan spek kepercayaan dari pelangganya. Namun berkaitan dengan layanan digital karena pelanggan tidak secara langsung melihat standart kualitas layananya pada saat melakukan pemesanan, maka tingkat kepercayaanya harus benar-benar dijaga. Layanan pariwisata digital yang mengandung unsur online sudah tentu memiliki kandungan persepsi resiko yang cukup tinggi. Karena itu harus bisa menumbuhkan rasa kepercayaan kepada penggunanya.

Tabel 11. Hasil kualitatif Theme Analytic Variabel Trust

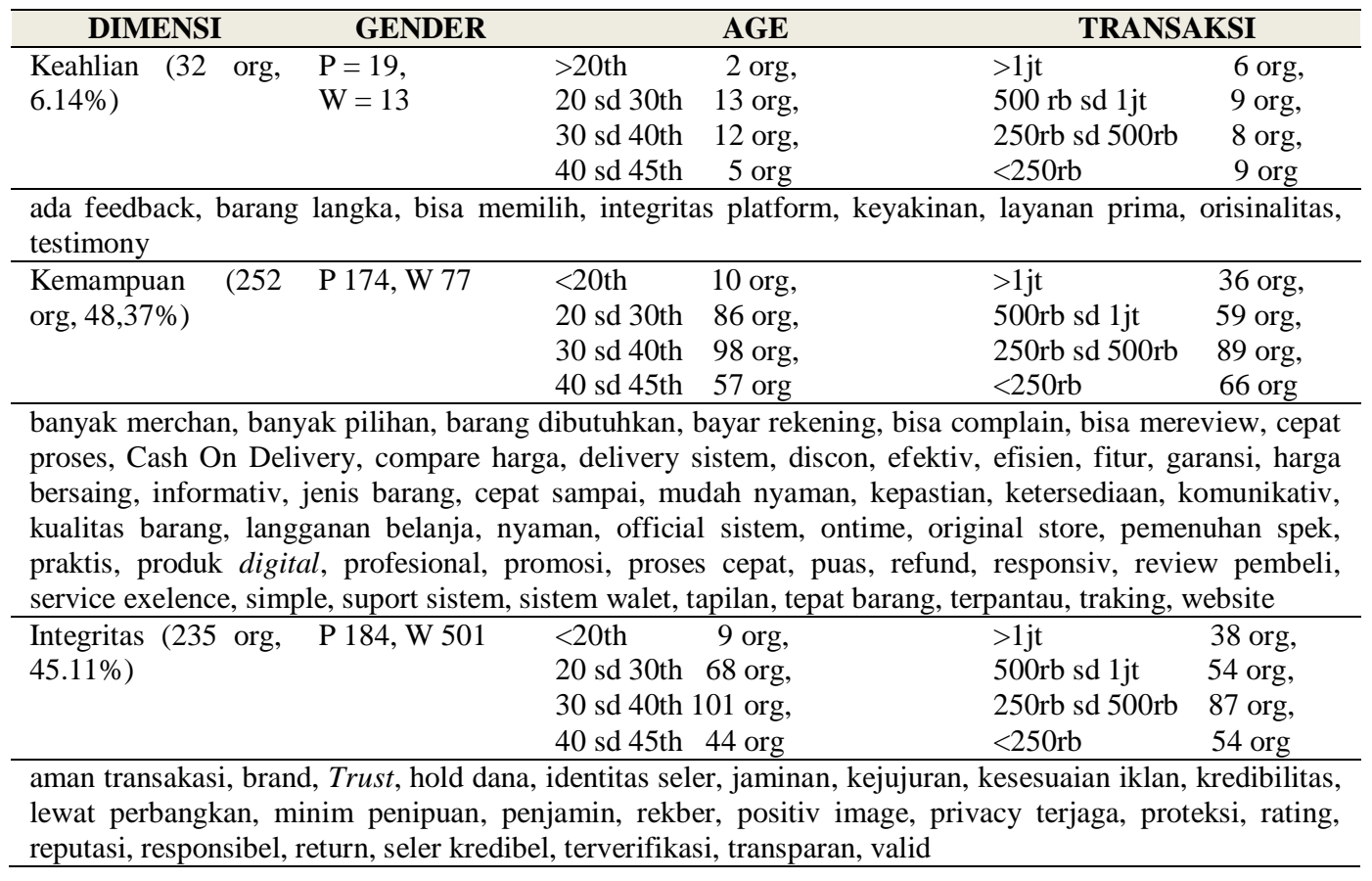

Hasil analisa kualitatif menunjukan faktor terbesar yang menentukan tingkat kepercayaan yaitu Kemampuan provider $48,37 \%$ dan diikuti oleh tingkat Integritas provider sebesar 45,11\% dengan profile merata disemua tingkatan usia.

\section{KESIMPULAN DAN REKOMENDASI}

Kesimpulan dari hasil penelitian ini adalah: Layanan pariwisata digital dalam pengembanganya harus memenuhi requirement yang mencakup faktor PE, EE, SI, FC, H, PR, PC dan T. Pemenuhan requirement untuk Faktor PE di titik beratkan pada dimensi dimensi Membantu Proses Pembelian sebesar 51,72\%. Pemenuhan requirement untuk Faktor EE di titik beratkan pada dimensi Merasa Ahli saat menggunakan layanan digital sebesar 45,06\%. Pemenuhan requirement untuk Faktor SI di titik beratkan
Hasil pengolahan secara kualitatif terhadap jawaban responden berkaitan Trust menunjukan bahwa jawaban terbanyak mengarah kepada dimensi kemampuan provider memberikan layanan dengan prima

pada dimensi Faktor Sosial penggunaan layanan digital sebesar $77,14 \%$. Pemenuhan requirement untuk Faktor FC di titik beratkan pada dimensi Ketersediaan Resource menggunakan layanan digital sebesar $68,06 \%$. Pemenuhan requirement untuk Faktor $\mathrm{H}$ di titik beratkan pada dimensi Pelaksanaan perilaku menggunakan layanan digital sebesar $68,68 \%$. Pemenuhan requirement untuk Faktor PR di titik beratkan pada dimensi resiko kerugian performansi 52,8\%. Pemenuhan requirement untuk Faktor PC di titik beratkan pada dimensi kenyamanan menggunakan layanan 
digital sebesar $31,05 \%$. Pemenuhan requirement untuk Faktor $\mathrm{T}$ di titik beratkan pada dimensi Kemampuan provider sebesar $48,37 \%$.

Pengembangan layanan pariwisata digital harus benar-benar mempertimbangkan faktor-faktor yang ada pada penelitian ini. Kunci keberhasilan pengambangan layanan digital adalah benarbenar memenuhi requirement digital consumer buying behavior yang merupakan faktor penting dalam konsep Market Driven pada era industry 4.0. Perlu dilakukan uji coba validasi terhadap layanan pariwisata digital yang ada untuk mengukur tingkat penerimaannya serta dilakukan program improvement.

\section{DAFTAR PUSTAKA}

Bapenas (2014), Rencana Pembangunan Jangka Menengah Nasional 2015-2019

Cravens, David W., (2013), Strategic Marketing (10th Edition), McGraw-Hill International Edition

Daduk Merdika Mansur (2019), Pengembangan model unified theory acceptance and use technology: study penerimaan dan penggunaan layanan kdigital di Indonesia, Disertasi doktor ilmu manajemen UNPAD

Khaniwale, (2015), Consumer Buying Behavior, International Journal of Innovation and Scientific Research, ISSN 2351-8014 Vol. 14 No. 2 Apr. 2015, pp. 278-286

Kannan and Li (2017), Digital Marketing: A Frame work, review and research agenda, International Journal of Research in Marketing 34 (2017) 22-45

Virginia Braun and Victoria Clarke (2014), Handbook of Research Methods in Psychology: Vol. 2. Research Designs, H. Cooper (Editor-in-Chief), DOI: 10.1037/13620-004 